\title{
An Ethnobotanical Comparison of Four Tribes of Amazonian Indians
}

\author{
Ghillean T, Prance \\ B. A. Krukoff Curator of Amazonian Botany, \\ The N. Y. Botanical Garden
}

\begin{abstract}
An ethnobotanical comparison is made between the four Indian tribes the Denis, the Jamamadis, the Makuis, and the Waikás. The data was collected during general plant collecting expeditions in the tribal areas, and is not presented as a complete ethnobotanical study of each tribe. It is a comparison of the botanical data which we were able to gather during short visits to each tribe. A table is given comparing the cultivated crops of each tribe. The following types of plant uses are discussed and compared: fish poisons, arrow poisons, other poisons, narcotic and hallucinogenic snuffs, coca, medicines, contraceptives, edible fruit and fungi and a few other miscellaneous plant uses. Information on the edible fungi eaten by the Waikás is presented for the first time. Various tables are given comparing the different plant uses by the four tribes. Reference is made to past observations and studies of the plants mentioned. Common to all four tribes are several of the most important food crops, fish poisons, some form of narcotic, arrow poisons, and various general uses of plants such as for building materials and body paints. Each tribe has a slightly different narcotic, the Jamamadis and Denis are most similar in this respect having a tobacco based snuff, the Waikás have several hallucinogenic snuffs and the Maku narcotic is coca which is eaten to remove hunger pains. The arrow poisons are also different from tribe to tribe. The Jamamadis and Denis have a Strychnos based curare, the Waikás a Virola, based poison, and the Makús a Moraceae based poison in which cardiac glycosides are present. The Jamamadis and Denís are ethnobotanically the most similar of the tribes compared and they are very different from both the Waikás and the Makús.
\end{abstract}

\section{INTRODUCTION}

During the year of plant collecting in Amazonian Brazil in 1971 on the collaborative program between the Instituto Nacional de Pesquisas da Amazônia and the New York Botanical Garden, we visited four very different Indian tribes. While we were in tribal areas, primarily to make general herbarium collections of the vegetation as part of our plant survey of Brazilian Amazonia we were also able to make, extensive ethnobotanical observations and collections from the four tribes which we visited. Three of the four tribes are now on the fringes of western civilization and they are rapidly becoming acculturated, therefore it is important to gather and record their botanical information before it is permanently lost. This study is not intended as a complete account of the ethnobotany of these tribes, but rather a record of plant uses which we observed while living amongst these four groups. Vouchers of all the herbarium material cited here are deposited at INPA, NY \& ECON.

\section{GENERAL INFORMATION ABOUT THE FOUR TRIBES}

\section{THE DENÍS}

The Deni village which we visited is situated on the upper Rio Cunhuá (marked as Rio Tapauá on most maps) at $6^{\circ} 21^{\prime} \mathrm{S}_{i} 67^{\circ} 40^{\prime} \mathrm{W}$. The Denis inhabit the region from the Rio Juruá up to west of the village which we visited. They have only recently come into regular contact with western civilization. The group which we visited is the most westernized village of the tribe and they even depend heavily upon local Brazilians to supplement their food supply, but they retain much of their own culture especially uses of plants.

\section{THE JAMAMADIS}

The Jamamadi village which we visited is situated about $120 \mathrm{~km}$ south of Lábrea on the Rio Apitua about four hours walk from the west bank of the Rio Purus at Seringal Jurucua. This 
group live close to Brazilians and work for the Seringal (rubber farm), but retain much of indigenous culture. Many members of the tribe still know and use plants as medicines, poisons etc. although they gather and sell rubber and Brazil nuts.

\section{THE MAKÚS}

The Makús inhabit the upper Rio Negro region. The group which we visited live on the upper reaches of the Rio Uneiuxi. This group is probably the most westernized of all four groups considered here. They are to some extent acculturated and work for a Brazilian gathering Sôrva latex (Couma sp.) and other forest products. A few of the younger adults have even had an elementary school education at the Salesian mission school in Tapuruquara. In spite of this the Makús retain much of their own culture, and still live in communal dwellings. The Makús were able to show us more plant uses than any of the other tribes, and they had a greater variety of their poisons and medicinal plants cultivated in their fields.

\section{THE WAIKÁS}

We have now visited a large number of Waiká (Yanomam) viliages in Roraima territory. During 1971 we walked a Waiká Indian trail from Serra dos Surucucus to the Rio

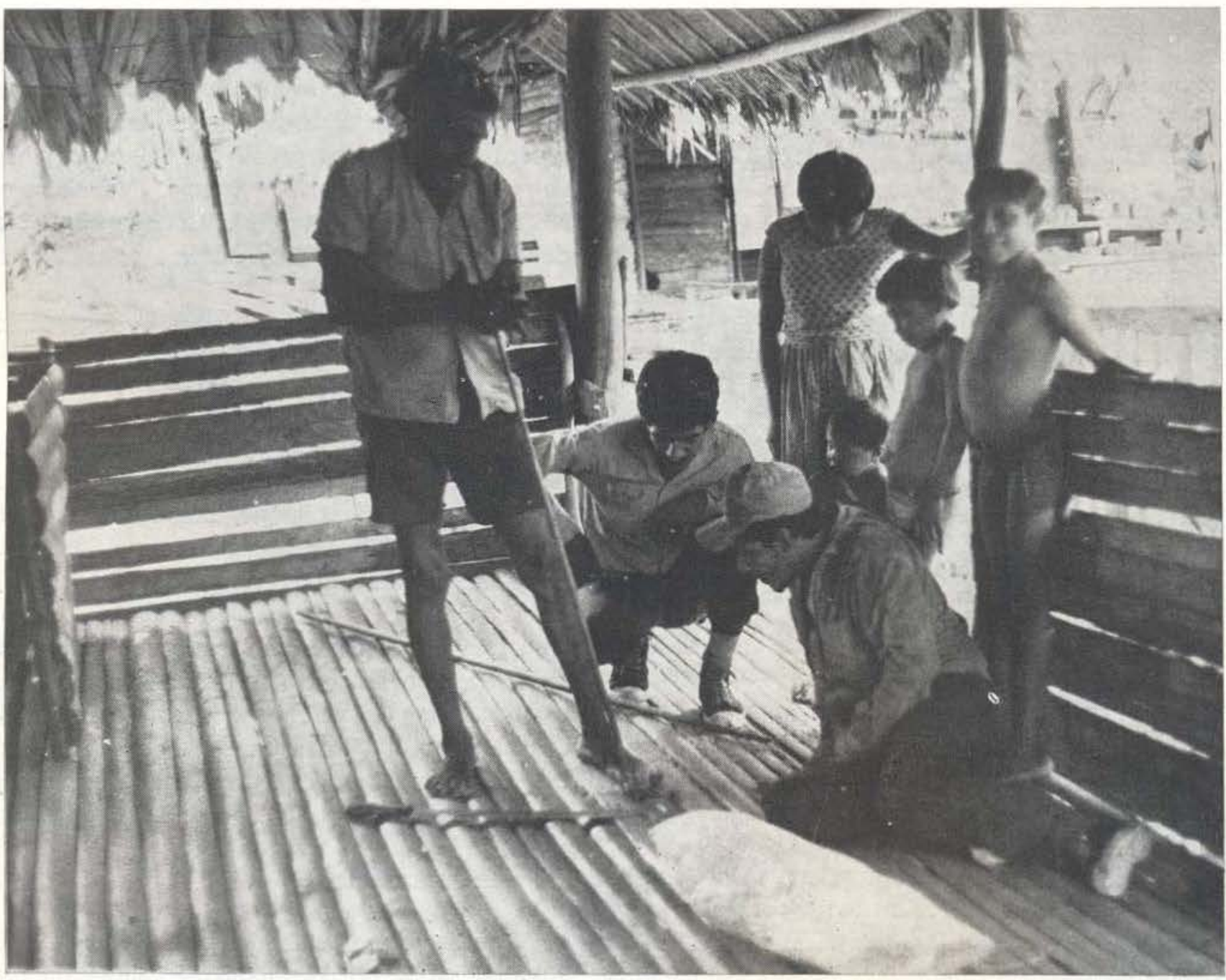

Fig. 1 - A Waiká Indian demonstrating their method of fire lighting to Osmarino Monteirı and José Ramos. The wood usually used for fire lighting by this grouy of Waikás on the Rio Mucajai is Croton pullei Lanj. var. pullei (Euphorbiaceae). 
Uraricoeira. This $200 \mathrm{~km}$ long trail passes through six different Waiká malocas. In this region the Waikás are virtually untouched by western civilization, apart from a little contact with missionaries living amongst them. These missionaries have wisely not encouraged the acculturation of the Indians. The Indians are living much as they have lived for hundreds of years. Their use of plants is not as great as that of some of the other tribes mentioned here. but they have some extremely interesting hallucinogenic plants which are important in Waiká culture.

\section{GENERAL BOTANY OF THE TRIBES}

These Indian tribes have a plant-based culture. It would be impossible to produce a comprehensive account of the plants which they use after the shori time which we spent with each of the four tribes. I have concentrated here on the most important and interesting plant uses, but also list some of the general uses. The Indians are using plant material to build their houses, thatch their rooves, carry their loads and butild their canoes. The Jamamadis, the Denis and the Makuis make abundant use of the palm Paxiuba (Socratea cxorrhiza (Mart.) Wendl.) which splits easily to make good floors and walls for their houses. All four tribes make abundant use of barks which strip and give a good band or rope for tying and making carriers etc. (known locally as Envira to Brazilians and coming mainly from the inner bark of trees of the Annonaceae and the Lecythidaceae). Each tribe eats a large variety of forest fruits.

\section{THE CROPS}

The crops which we actually observed under cultivation during visits made to the fields of each of the tribes are summarized in

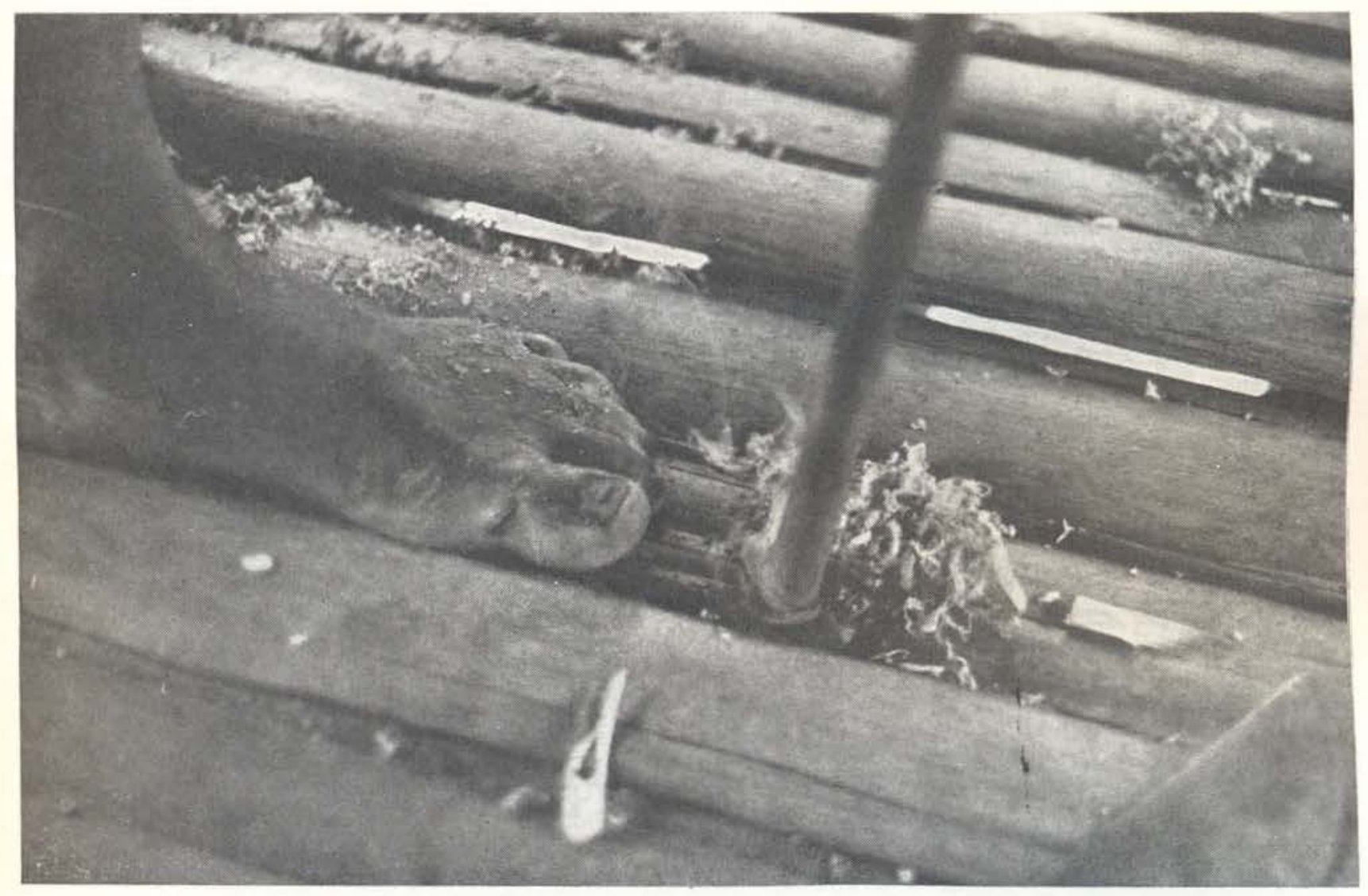

Fig, 2 - Close-up of the fire lighting procedure. One stick is spun in a hollow in another which is filled with tinder. The Indians prepare the soft wood of Croton by hardening over a fire and they then keep a stock of hardened wood. 
Table 1. The apparent paucity of Deni Indian crops is possibly due to the fact that the group which we visited had moved to that location only recently. They spoke of other crops which they grew in their other villages, and they were planning a journey to various villages of the tribe to collect seeds and propagules of other crops.

\begin{tabular}{|c|c|c|c|c|}
\hline Food Crops & Dení & Jamamadi & Makú & Wail \\
\hline Abiú (Sapotaceae fruit) & - & - & + & - \\
\hline Avocado & - & - & $+(1$ tree $)$ & - \\
\hline Banana - cooking plantain & + & + & + & + \\
\hline sweet & + & + & + & + \\
\hline Casava - Bitter & + & + & + & + \\
\hline sweet & + & + & + & + \\
\hline Cashew & + & + & - & - \\
\hline Corn & + & + & + & + \\
\hline Cará & + & + & + & + \\
\hline Inga (edible aril in pods) & - & - & + & - \\
\hline Lemon & - & + & - & - \\
\hline Mango & - & + & - & - \\
\hline Millet & - & - & + & - \\
\hline Papaya & + & + & - & + \\
\hline Pineapple & - & + & + & + \\
\hline Pupunha palm (Guilielma speciosa Mart.) & - & + & + & + \\
\hline Squash & + & - & - & - \\
\hline Sugar cane & + & + & + & + \\
\hline Sweet potatoe & + & - & + & - \\
\hline Tarrow & - & + & - & + \\
\hline \multicolumn{5}{|l|}{ Non-food crops } \\
\hline \multicolumn{5}{|l|}{ Carawá, fish poison } \\
\hline (Euphorbia cotinifolia L.) & - & - & + & - \\
\hline Cunambi, fish poison (Clibadium) & + & - & + & - \\
\hline Timbó, fish poison (Lonchocarpus) & - & + & + & + \\
\hline Bixa orellana (dye) & + & + & + & + \\
\hline Cotton & + & + & + & + \\
\hline Flecheira (P 10530) used arrow shafts & & & & \\
\hline Gynerium sagittatum (Aubl.) Beauv. & + & - & - & + \\
\hline Gourds & - & + & - & + \\
\hline Ipadu ('coca' = Erythroxylum coca L.) & - & - & + & - \\
\hline Tobacco & + & + & - & + \\
\hline
\end{tabular}

Table 1. A comparison of the crops of the four groups discussed.

\section{PLANTS USED}

\section{FISH POISONS}

The use of fish poisons by Indians has been known and discussed for many years e.g. Ernst (1881), Lecointe (1936). Summaries of the subject were given in Killip (1931) and Krukoff \& Smith (1937). The active ingredient of many of the poisons are the rotenones which are also used as insecticides. All four tribes use fish poisons regularly and they are important in the life of the tribes.
The poison is placed into small creeks, and fish are poisoned or asphyxiated for a considerable distance down river. It is a drastic way of fishing as even the smallest fish are poisoned, and all four tribes use it only for special occasions. Poisoning usually provides a large amount of fish and even the smallest fish are collected and eaten.

Eight different species of plants are used in the four tribes, and different parts of the plants are used. The sap of the poison plant is put into the water, although methods vary 
between tribes. The Waikás use the woody stem of the large vine of Lonchocarpus nicou (Aubl.) DC. This is beaten with a hard stick (Fig. 3.) and then thrown into the water which is agitated to stir up the mud. The Makú make one of their poisons from the leaves of Euphorbia cotinifolia L., and they place large packs of leaves on a stand over the river. They beat the leaves, and throw water over the beaten leaves to let the juices drop down into the river (Fig. 4). The men do this leaf beating while the women stand up-river and agitate the river to stir up as much mud as possible. The poisons are nearly always used in muddy waters. The Makús also use the pericarp of the fruit of Caryocar glabrum (Aubl.) Pers. which they collect, grind up and mix with mud a few days prior to a fishing party. The Waiká use the Lonchocarpus poison in open rivers to poison large fish, but they use Clibadium sylvestre (Aubl.) Baill, to poison small tish in dammed up creeks. I have usually observed the poisoning in undammed rivers and creeks. Table 2 summarizes the fish poisons observed in the four tribes studied.

\begin{tabular}{|c|c|c|c|c|c|c|c|c|}
\hline Source of Poison & Part of Plant & Dení & Jamamadi & Makú & Waiká & & $\begin{array}{l}\text { oucher: } \\
\text { ance } \mathbf{N}\end{array}$ & \\
\hline $\begin{array}{l}\text { Caryocar glabrum } \\
\text { (Aubl.) Pers. }\end{array}$ & pericarp of fruit & - & - & + & - & 15576, & 15583 & \\
\hline $\begin{array}{l}\text { Clibadium sylvestre } \\
\text { (Aubl.) Baill. }\end{array}$ & Iruit & + & - & + & + & 16496, & 15555 & 10529 \\
\hline $\begin{array}{l}\text { Derris latifolia } \\
\text { HBK }\end{array}$ & roots & - & + & - & - & 13930 & & \\
\hline $\begin{array}{l}\text { Euphorbia cotinifolia } \\
\text { L. }\end{array}$ & leaves & - & - & + & - & 15554 & & \\
\hline $\begin{array}{l}\text { Lonchocarpus nicou } \\
\text { (Aubl.) DC. }\end{array}$ & stems & - & - & - & + & 13601 & & \\
\hline $\begin{array}{l}\text { Lorchocarpus urucu } \\
\text { Killip \& Smith }\end{array}$ & stems & - & - & + & - & 15573 & & \\
\hline $\begin{array}{l}\text { Lonchocarpus cf. } \\
\text { utilis A. C. Smith }\end{array}$ & stems & - & - & - & + & 11110 & & \\
\hline $\begin{array}{l}\text { Phyllanthus } \\
\text { brasiliensis (Aubl.) } \\
\text { Poir. }\end{array}$ & leaves & - & - & + & - & 15556 & & \\
\hline
\end{tabular}

\section{ARROW POISONS}

All four tribes use poisonous arrows and/or blow gun darts. The Dení poison was not collected but is probably Strychnos based and rather similar to that of the Jamamadi. The Makú and Waiká poisons are different from each other and from that of the Jamamadi.

The Jamamadi have a curare arrow poison based on Strychnos and Curarea. The contents of the poisons is the following :

Strychnos solimoesana Krukoff, (Prance et al. 13929), "Irã".

Curarea toxicofera (Wedd.) Barneby \& Krukoff, (Prance et al. 13931), "Bicava".

Guatteria cf. megalophylla Diels (Prance et al. 13936), "Boa".
Fagara sp. (Prance et al. 13937), "Balala".

The poison is prepared from a mixture of the bark of all four of the above species, with the Strychnos (Fig. 5, 6.) and Curarea being used in greater quantites than the other two, and more Strychnos than Curarea. The bark mixture is heated, boiled and concentrated into a sticky residue which is then used to coat blow gun darts (Fig. 7). This Strychnos based arrow poison or curare is probably the best known and the most describe arrow poison. It varies from tribe to tribe, but has essentially the same paralyzing effect on the victim.

The species of Strychnos used, S. solimoesana, was first reported as the principal ingredient of a curare in Krukoff (1965), where it is cited as the main constituent of the Cauichana 


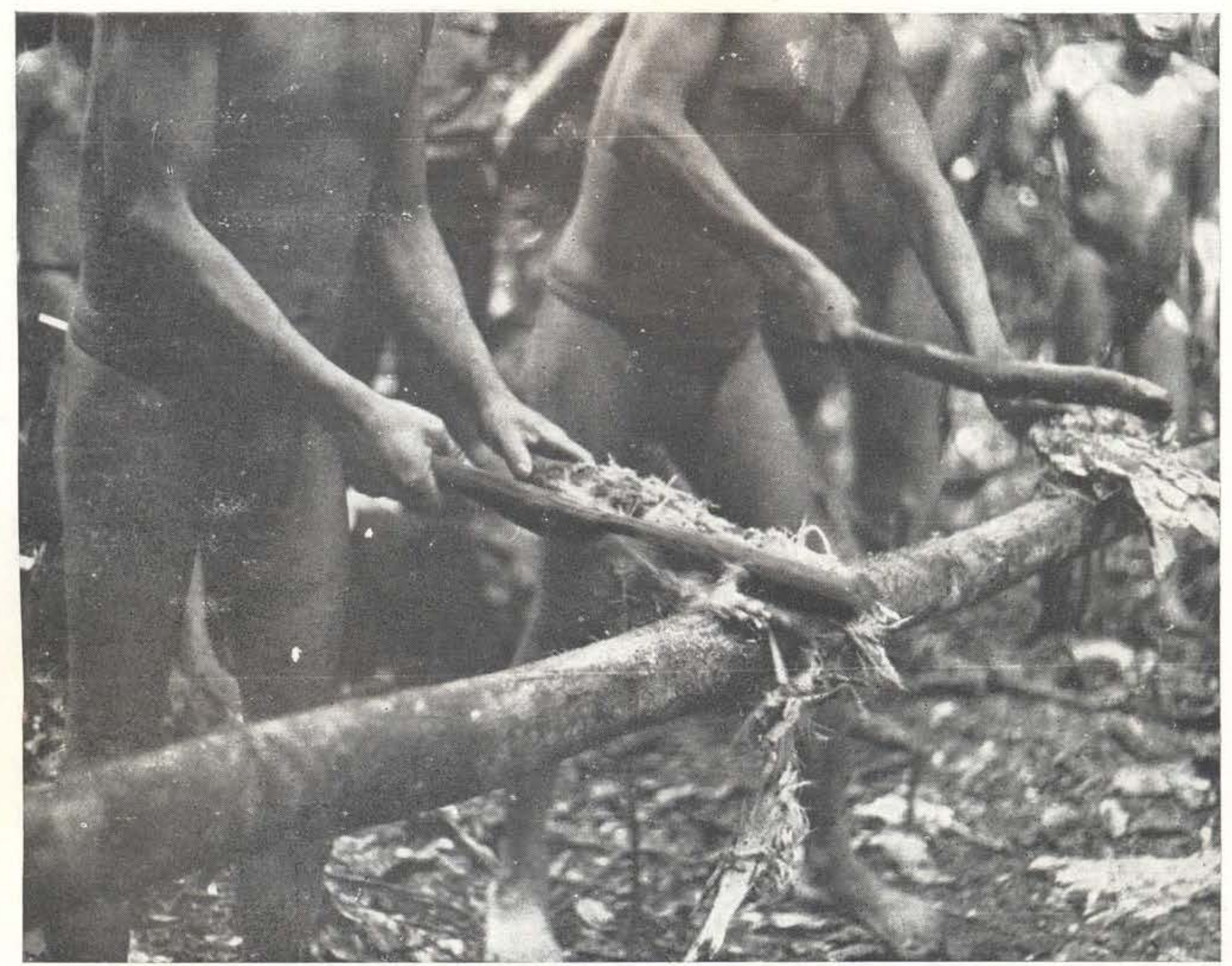

Fig. 3 - Waiká Indians preparing fish poison by beating out the stem of Lonchocarpus nicou (Aubl.) DC. Photographed on the Surucucu-Waiká trail.

Indian arrow poison. The Cauichana live on the Rio Tocantins. S. solimoesana was studied chemically by Barredo-Carneiro (1938) who isolated two alkaloids stricholetaline and curaletaline from the stem bark, and by MariniBettolo (1957) and associates who detected the presence of 40 alkaloids in the stem bark. The latter authors list all these alkaloids, 14 of which were new. S. solimoesana based poison is said to be one of the most powerful and effective paralyzing curares.

Curarea toxicofera is discussed as an arrow poison ingredient in Krukoff \& Barneby (1970) under Chondrodedron toxicoferum, and is also mentioned in Barneby \& Krukoff (1971). Various members of the Annonaceae have also been reported as arrow poison ingredients, but not the above species. For example Unonopsis veneficiorum (Mart.) R.E. Fries is reported as an ingredient of curare by Schultes (1969).

The Makús have an equally effective poison which is much more easily prepared since it has only one ingredient; the latex of the Moraceous tree Naucleopsis mello-barretoi (Standl.) C.C. Berg (Prance et al 15563). A small slit is made in the bark of the tree, and the latex is collected into a leaf. (Fig. 8). This is coated directly onto blow gun darts, and requires no intermediate heating or concentration process. Presumably the active ingredients of this poison are the cardiac glycosides which the genus Naucleopsis is known to contain. They are presently under 
study by Dr. N.G. Bissett of the Chelsea College of Pharmacy, London, who has received a sample of the poison which we collected. The poison of the Makús affects the heart whereas the curare of the Jamamadis is a poison affecting the nervous system.

The Waikás in the Serra do Surucucus region of Roraima use the bark resin of the Myristicaceous tree Virola theiodora (Spruce ex Benth.) Warb. (Prance et al 10685, 10984) as their arrow and dart poison, and it is also the source of their hallucinogenic snuif. The bark is stripped off trees and then placed over a fire. The heat causes much resin to ooze out. This is then collected into gourds for use as a snuff or poison. This dual use of $V$. theiodora as snuff and arrow poison was reported in Schultes (1968) and I have already discussed it in Prance (1970). The tryptamines are the active ingredients of the hallucinogenic snuff, but little is known about the active ingredients of the arrow poison. This poison acts more slowly than the other two described. The Waikás have to follow game shot with their poison and it will take up to 20 minutes for the victim to fall whereas a chicken shot with a Jamamadi dart fell over and was paralyzed within 10 seconds of being hit with a blow gun dart coated with fresh poison.

These three completely different arrow poisons demonstrate the diverse plant culture of the different Amazonian tribes. It also shows the versatility and flexibility of the Indians as their separate cultures developed. As they colonized or were driven into new areas presumably they experimented and found new

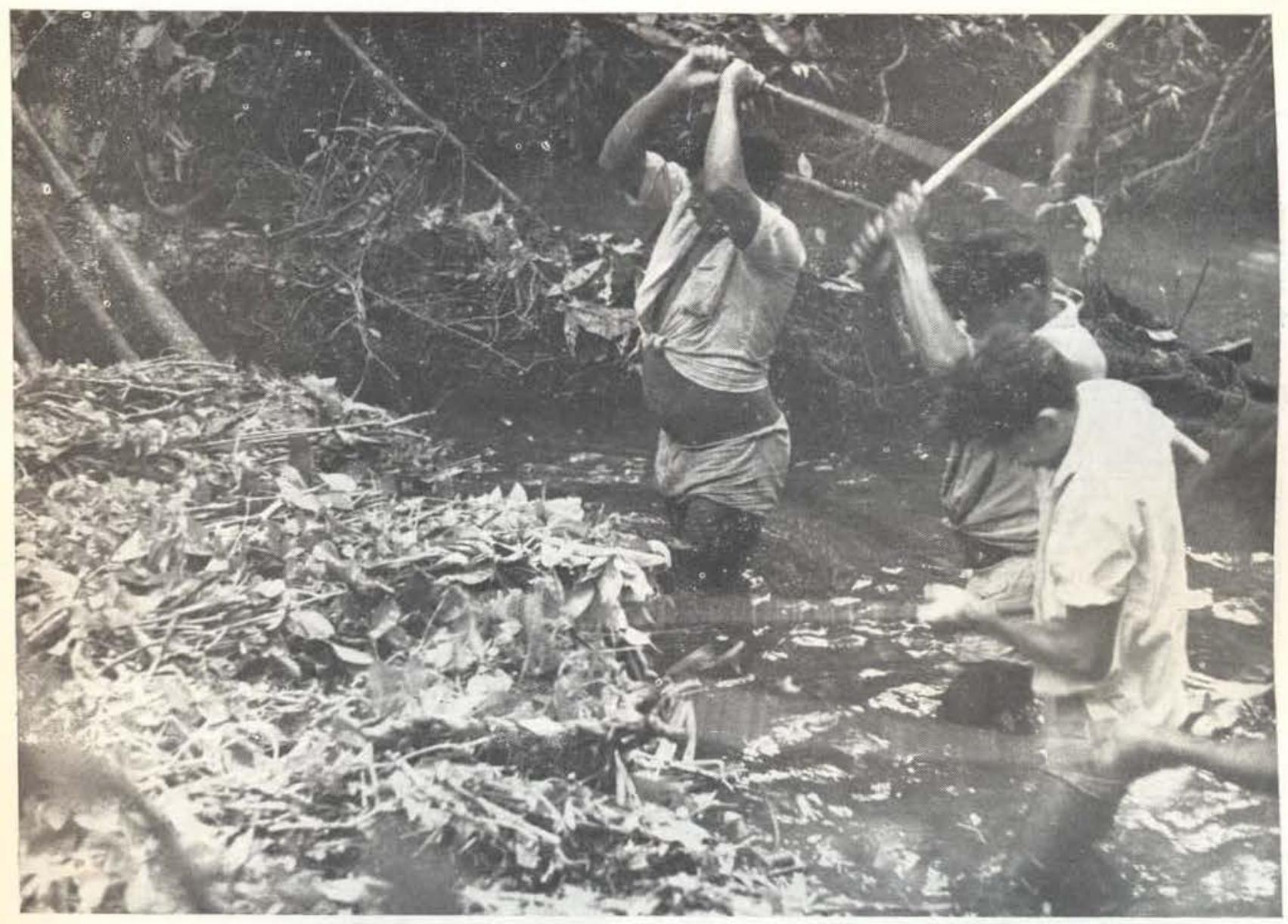

Fig. 4 - The Makús prepare their fish poison directly over the water of a small creek. Here they are pounding the leaves of Euphorbia continifolia L. with sticks. The poison falls into the creek. The Indians must turn their eyes away from the splashes of the plant latex as it causes blindness. 


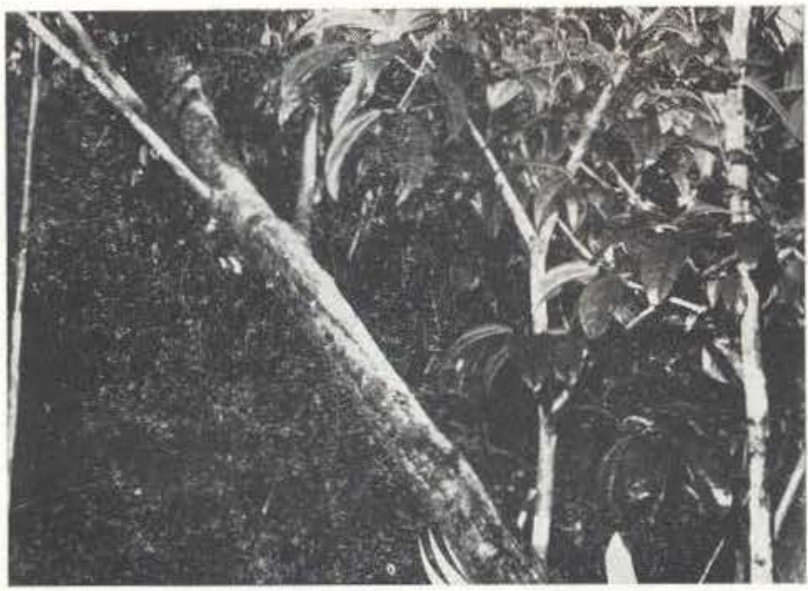

Fig. 5 - Strychnos solimoesana Krukoff, the source of the Jamamadi arrow poison. Much of the bark has been removed to obtain poison.

poisons from the local plant resources as they could no longer use the poisons from their previous locations.

\section{OTHER POISONS}

As various poisons have been discussed in other literature we questioned all four tribes about the existence of poisons other than the arrow and fish poisons. Only the Makús appear to have other poisons which were used frequently to poison animals and humans. Samples of two poisons were collected; both made from members of the Flacourtiaceae, a family well know as a source of poisons.

The poison which the Makús call "Warapash" is obtained from Carpotroche Amazonica

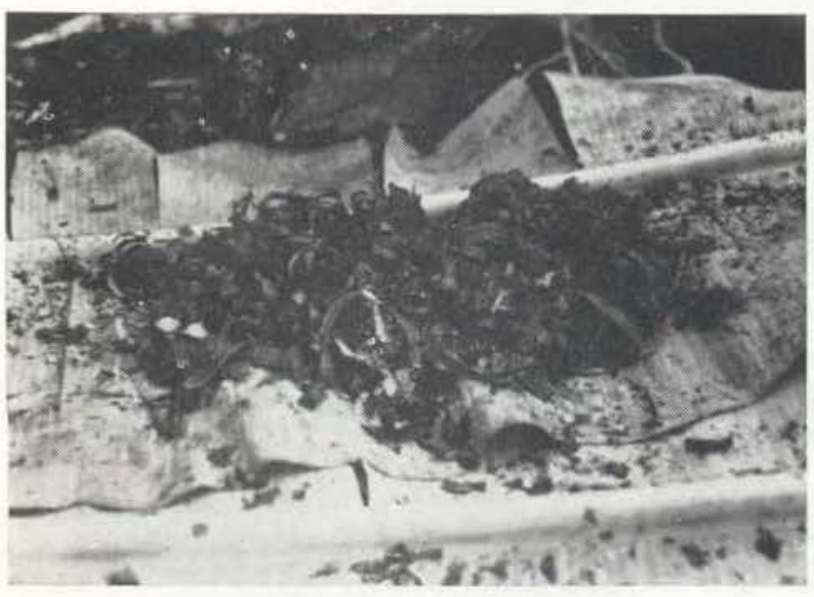

Fig. 6-The bark of Strychnos solimoesans Krukoff on a banana leaf ready for mixing with the other ingredients of the Jamamadi Curare.
Mart. (Prance et al. 15584). It is used to poison armadillos. Bark is scraped from the these and is heaped at the mouth of armadillo burrows. The armadillos apparently like the bark, eat it, and die nearby, providing the Makú diet with armadillo meat.

"Caramã", the other Makú poison is from the bark of Ryania speciosa Vahl var. minor Monachino. It is made by mixing the stem bark with food, and it works rapidily. Until quite recently it was taken by old people to commit suicide; a type of euthanasia which was acceptable in this tribe, the poison was also used for enemies, but the Makú group which we visited was no longer using it in these ways.

Ryania speciosa is a well known poisonous plant which contains the alkaloid ryanodine which has been much used as an insecticide. A summary of the uses and a bibliography referring to literature on ryanodine are given in Monachino (1949).

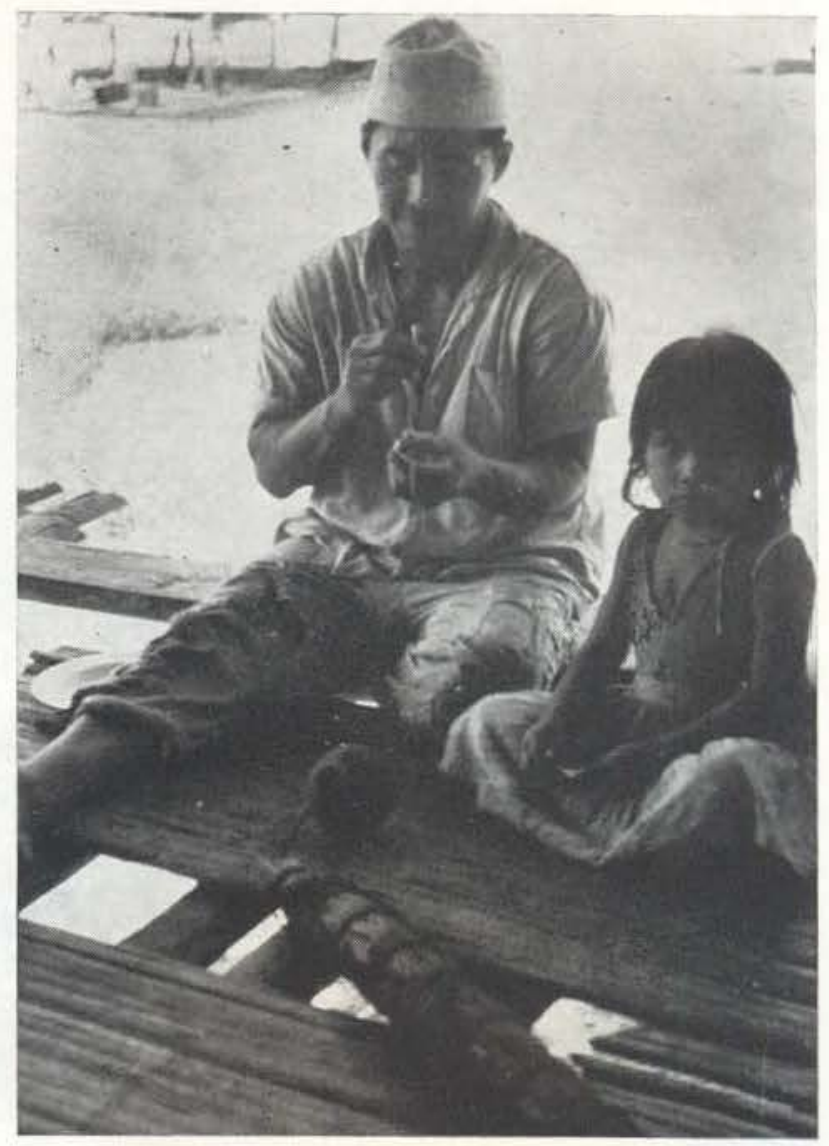

Fig. 7 - A Jamamadi Indian prepares a blow gun dart poisoned with their Curare. 


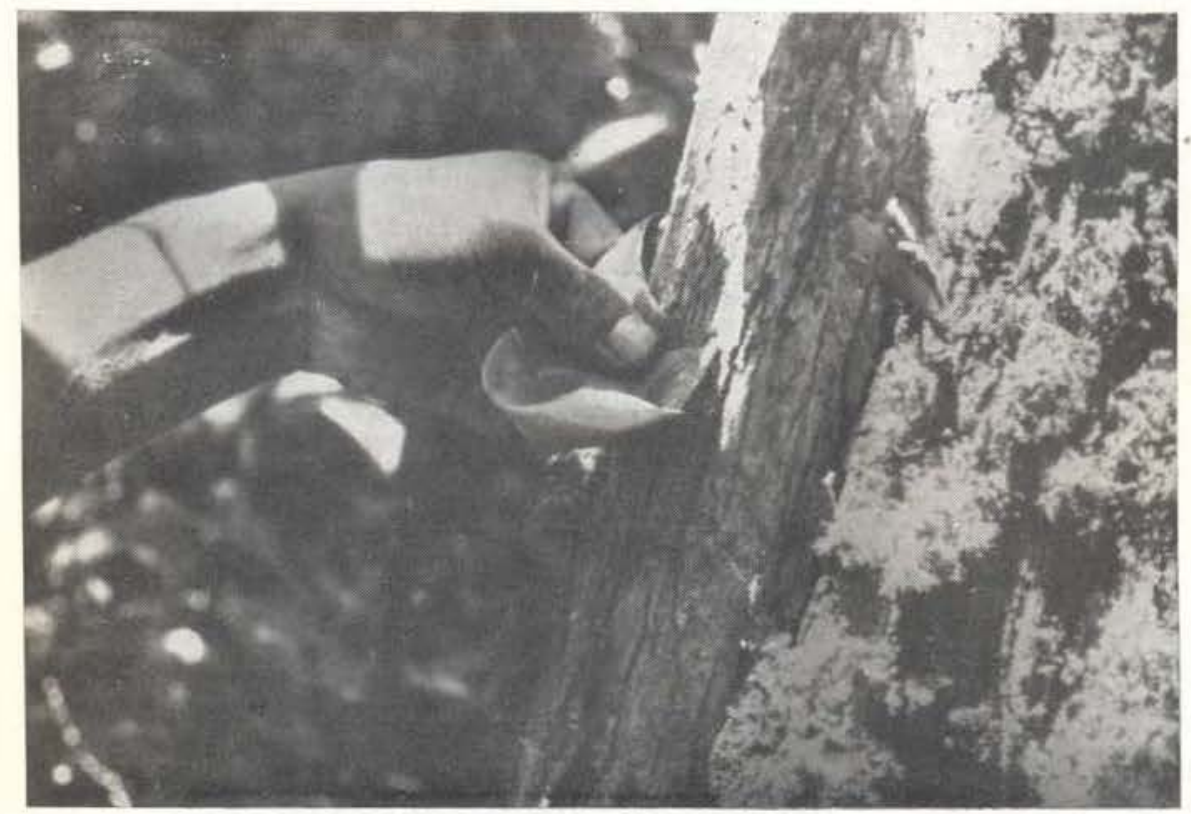

Fig. 8-A Makú Indian extracting the late of Naucleopsis mello-barretoi (Standl. Berg. The latex is coated directly onto their blow gun darts and is an effective poison. (Photo by D. Woolcott).

\section{SNUFFS}

The Makús are the only tribe that do not have a narcotic snuff. The other three tribes each have a snuff that plays an important role in their tribal life. The Makús have a form of Côca as a narcotic instead of a snuff. The snuff of the Waikás is hallucinogenic whereas that of the Jamamadis and Denis is intoxicating but not hallucinogenic.

Dení and Jamamadi

These two tribes have essentially the same snuff which is based on tobacco (Nicotiana tabacum L., Prance et al. 13928), mixed with the bark ash of various species of Cacai: (e. g. Theobroma subincanum Mart., Prance et al. 13933, 13939, 16515). The snuff is called by the same name in both tribes which have different languages, Shinã by the Jamamadis and Tsinã by the Denis.

The tobacco leaves are gathered and heated on top of a convex metal bowl, and are rolled with a wooden rolling-pin to squeeze out all the juices. It takes about 20 minutes to dry the leaves crisp by this process. At the same time o fire is made from the bark of the Cacau (Theobroma). When the leaves are crisp and dry they are broken up into a wooden bowl and ground into a fine powder with a wooden pestle. (Fig. 9). At the same time ash from the Cacau

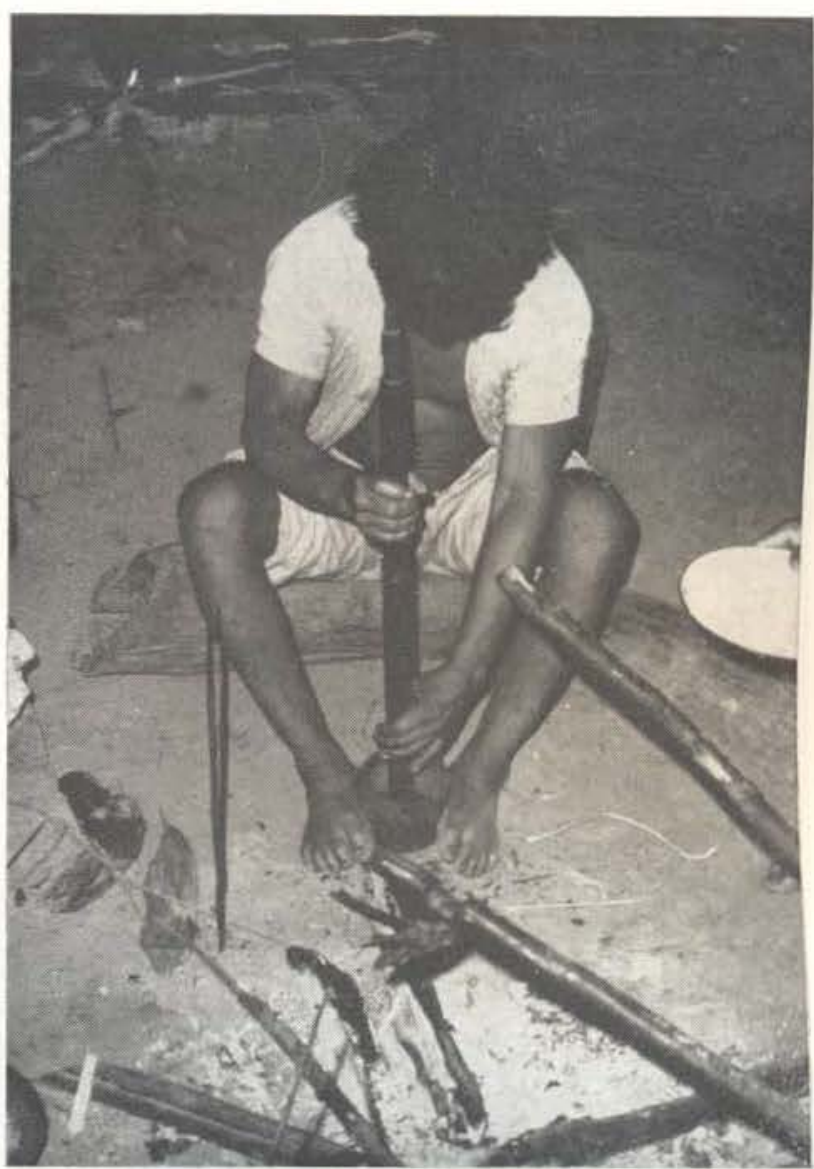

Fig. 9 - A Jamamadi prepares their narcotic snuff Dried tobacco leaves and cacau ashes are being ground together by using this primitive mortar and pestle. 
bark is added in roughly equal quantities. The snuff is then ready for use. The group definitely prefers fresh snuff, and appears to make it most evenings. Most members of the tribe carry a small amount of the snuff with them in an assortment of containers.

The snuff is administered by sucking it into the nostrils through a small pipe made from a hollow monkey leg bone. (Fig 10) One person will hold out the snuff on a leaf while the other takes it, drawing in turn into each nostril. Almost all the tribe including children carried the bone pipes.

The snuff has an intoxicating effect on the user. The users appear inebriated and they talk of light headedness. This snuff is certainly a powerful intoxicant, but it is not hallucinogenic as no one spoke of hallucinations in connection with it. The Jamamadis appear to take it from

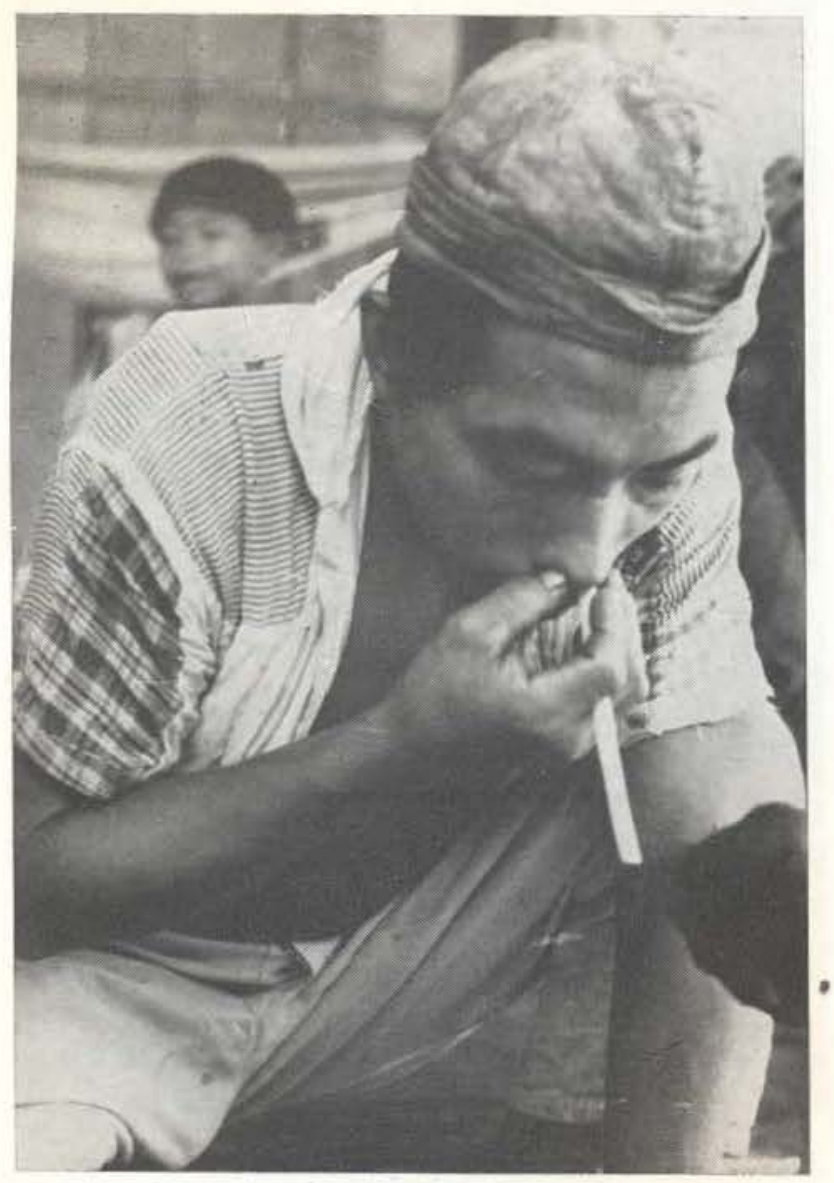

Fig. $10-$ A Jamamadi taking a dose of their snuff, by drawing it into his nostrils through a hollow monkey bone. early childhood since we observed a four year old taking it regularly, and a ten year old girl traded her supply of snuff and her pipe with us.

The Indians are insistant that the snuff is ineffective without the Theobroma bark ash, and said that they never take a pure tobacco snuff. The use of this tobacco-cacau snutf covers quite a large area of Amazonia between the hios Purus and Jurua, the range of these two tribes and of other tribes which use the same snuff.

The Denís have a second snuff called Badhu (= deer $)$ - tsina $(=$ snutt $)$. This is collected trom a pyrenocarpous lichen (France et al. í603). Untortunately due to the stage of uevelopment of the lichen when collected and when used as a snurt, rurtner identirication is not possidie. Ine yenow powaer or the medulla on the surrace or the licnen is collected trom the tree trunks where it grows. This is then sniffed in small quantities. It does not appear to have a narcotic effect, but rather to cause extreme irritation and a tingling sensation in the mucous membranes of the nose. When we sniffed it we were all seized by a violent attack of sneezing much to the amusement of everyone present. This snuff is taken quite frequently by the Denís and causes sneezing.

\section{Waiká}

The hallucinogenic snuffs of the Waikas have been described and discussed in many recent publications e.g. Schultes \& Holmstedt (1968) \& Schultes (1969b), and I have described their use in Prance (1970). Consequently no more than a summary is given here. The Waikás have two different sources of snuff, but most individual villages use only one type. The snuffs are prepared either from Virola (Myristicaceae) or Piptadenia (Mimosoideae).

\section{A. Virola based snuffs}

The use of Virola for snuff is widespread in the northwest of Amazonia. I have now observed its use in six Waiká groups in Roraima Territory at Auaris, Serra dos Surucucus, Maitá, Rio Uraricoeira, Surucucus-Uaicá trail, and at Posto Mucajai, as well as at one locality in Amazonas, Tototobí. 
The main source of snuff is the bark of Virola theiodora (Spruce ex Benth). Warb. which may or may not be mixed with additional

$\begin{array}{lll}\text { Group } & \text { Locality } & \text { Species } \\ \text { Sanama } & \text { Auaris } & \text { Virola theiodora } \\ \text { Parimiteri } & \text { Uraricoeira } & \text { Virola theiodora } \\ \text { Ninam } & \text { Posto Mucajaí } & \text { Virola theiodora } \\ \text { Maitá } & \text { Maitá } & \text { Justicia pectoralis } \\ \text { Ninam } & \text { Posto Mucajaí } & \text { Justicia pectoralis }\end{array}$

plant ingredients, mainly Justicia pectoris Jacq (Acanthaceae). A summary of the material collected is given in the Table.

$\begin{array}{ll}\text { Voucher Herbarium Number } & \text { Local Name } \\ \text { Prance et al. 9638, 9684 } & \\ \text { Prance et al. } 10685 & \text { Mashfara-á } \\ \text { Prance et al. } 10984 & \text { Tchkiana } \\ \text { Prance et al. } 10531 & \text { Mashfarahenak } \\ \text { Prance et. al } 11174 & \text { Paxararok }\end{array}$

Table 3. Material collected of Waiká snuff plants.

The Virola bark is stripped from the iree and heated over a fire. The heat causes the resin to ooze out of the bark. This is then collected into gourds or applied directly to arrow heads for use as a poison. The dried resin is then pulverized and, in some villages, mixed with Justicia. The exact procedure of preparation varies considerably form village to village. At Surucucus the only method of storage appears to be on arrow heads. The powder is then ready for use and, unlike the Jamamadis and Denís, the Waikás use it only for especial occasions. It is taken mainly by the Shamans before curing a patient, and by the adults of the whole village to culminate the final day rituals after the death a member of the village. It is also taken following certain hunting parties.

The active compounds are found in the Virola which contains hallucinatory tryptamines. Virola theiodora resin contains approximately

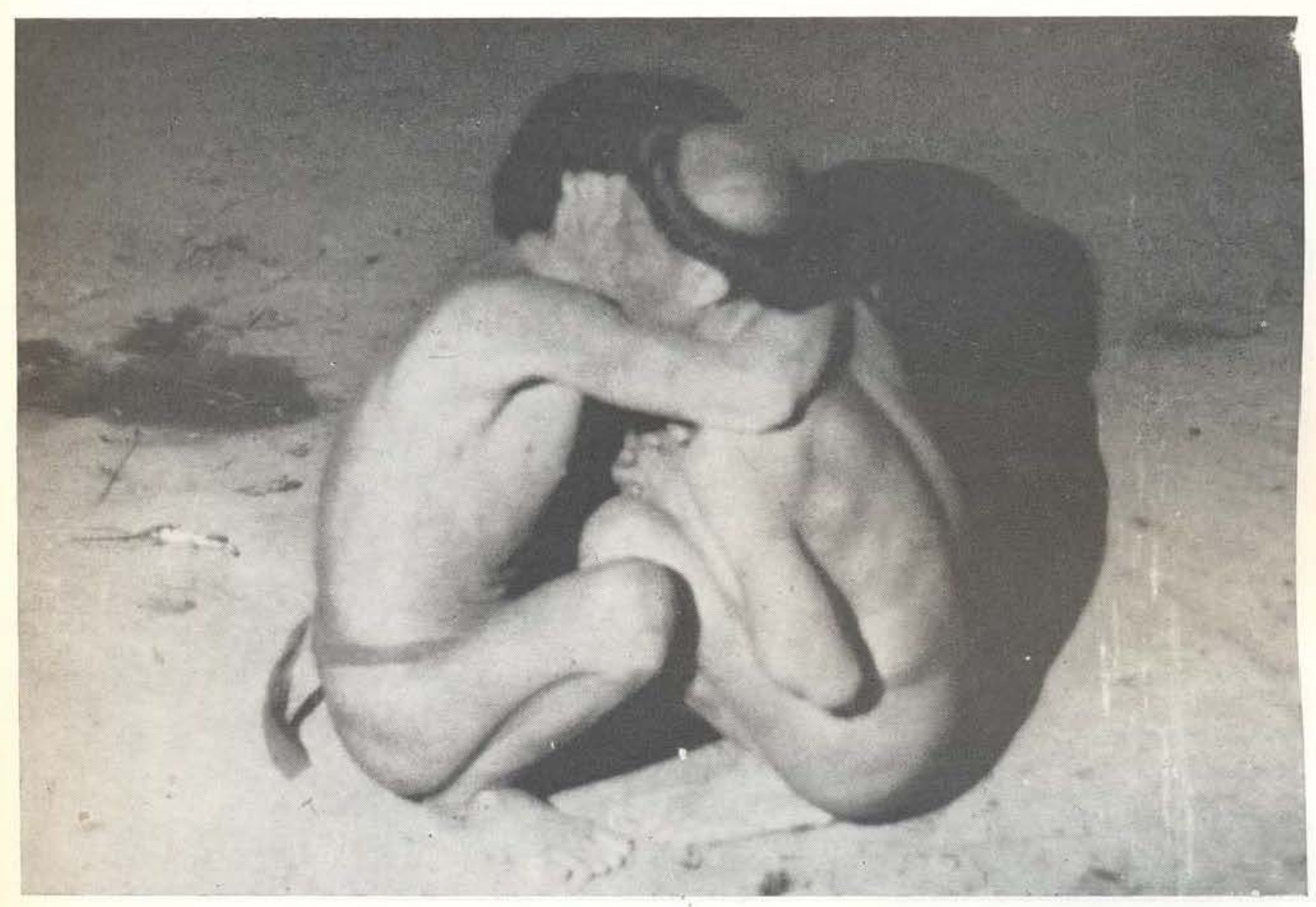

Fig. 11 - Waiká Indians crouched down in a shouting ceremony which is part of their ritual following a dose of their hallucinogenic snuff. 
$8 \% 5$ methoxy $\mathrm{N}, \mathrm{N}$-dimethyltryptamine, $\mathrm{N}$. $\mathrm{N}$-dimethyltryptamine and is consequently an effective hallucinogen. No active ingredients have yet been found in Justicia which is added for aromatic purposes.

The Indians administer the snuff with small blow pipes. One Indians blows snuff into another's nostrils to introduce a sufficient quantity. The intoxication is rapid and powerful. The ceremony which follows the administration of the snuff is described in Prance (1970) where it is shown how they participate in a chest hitting ritual, followed by a shouting ritual, during which they commune with their spirits.

\section{B. Piptadenia based snuffs}

The use of Piptadenia peregrina (L.) Benth, for a hallucinogenic snuff was reviewed by Schultes $(1954,1963)$. During a field trip on the upper Rio Negro in 1971 we came across a group of Waikás from the Rio Marauiá returning from a canoe trip to collect Piptadenia truit for their snuff. This snuff is made from the roasted, dried and pulverized seeds of Piptadenia pere. grina (L.) Benth. (Prance et al 15.125). (Fig. 12.) Piptadenia snuff is more intoxicating and consequently more dangerous than Virola snuff since the active alkaloid is bufotenin which is a powerful hallucinogen.

The Waikás from the Rio Marauiá make a long canoe trip annually to the mouth of the Rio Uneiuxi to collect Piptadenia seeds, as the trees do not grow where they live. The possession of a hallucinogen seems to be an essential part of Waiká culture as they will travel a long way to obtain their material for the snuff. Wherever they live they appear to have a snuff. However, it is not for general everyday consumption and is used only on the proper occasions. They could not be classed as addicts to their snuffs which are only used under controlled circumstances.

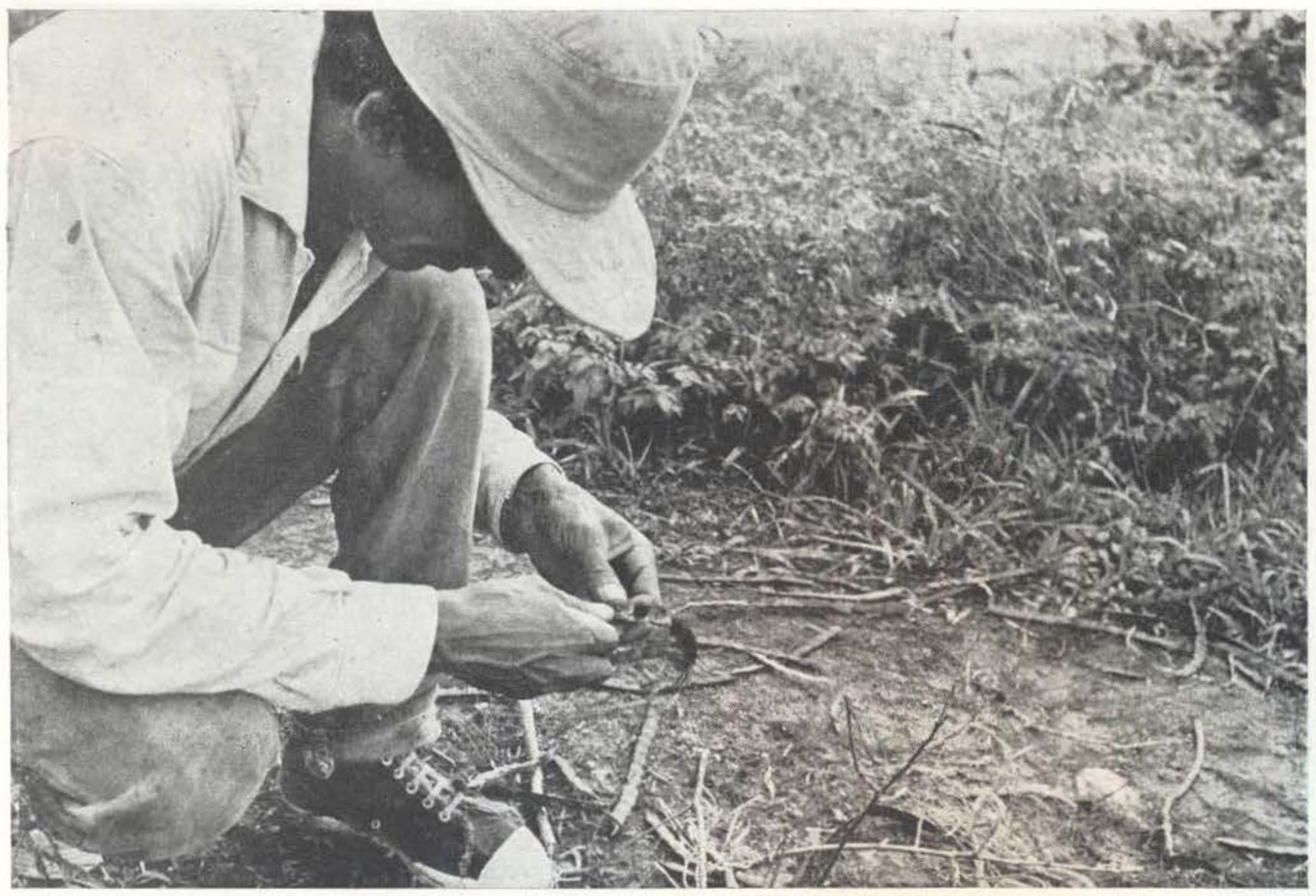

Fig 12 - Osmarino extracting the seeds of Piptadenia peregrina (L.) Benth. The seeds are used by the Waika Indians of the upper Rio Negro for their hallucinogenic snuff. 
In contrast the tribes which have a tobacco based snuff are truly addicted to their snuffs. The Jamamadis and Denís take their snuff daily, and even small children take it. The use of the Waiká snuff is strictly confined to adults.

\section{THE MAKÚ COCA}

It was already observed above that the Makús do not have a narcotic snuff. However, it seems that most Indian tribes have a narcotic of some sort, and the Makús are no exception since they use Coca (Erythroxylum coca L. Prance et al 15572) which they call Botô and which is known to local Brazilians as Ipadu.

The Makús cultivated the Coca plant in large quantities in their fields. The leaves are harvested and placed in a large flat pan to toast until they are crisp and dry. (Fig. 13). At the same time a fire is made and green banana leaves are burned. The dried leaves are placed in a wooden bowl and ground into a powder and mixed with the banana leaf ash. There is a ceremony attached to the pulverizing, and a rhythm is often beaten out with the wooden grinding stick while other Indians chant. The extremely deep, long, hollow mortar which they use makes a loud drum-like noise when the wooden pestle is knocked against the side. The different rhythms which they beat tell the rest of the Indians how the preparation is progressing. When the ash and leaves are ground into a fine powder they are ready for use. The powder is mixed with casava either with farinha flour or tapioca flour. This powder from coca forms a part of the daily diet of the Makús, and they prepare it fresh every evening. The powder is not unpleasant to eat, it tastes only of dried leaves, and did not have any adverse effect on the members of our expedition who sampled it.

Other reports on the use of coca by the lowland Amazon tribes, e.g. Schultes (1957) described the preparation of coca leaves by pulverization as given below, but the method of use is generally different from that of the Makus. Coca is more often taken into the mouth and slowly worked with the tongue into a packed mass between the cheek and the gums.
This mass is dissolved slowly rather than eater. with food as in the case of the Makús.

\section{MEDICINES}

As would be expected, each of the tribes visited use medicines prepared from plants. The Waikás use them less than the other rribes, and have less medicine culture than the others; as they depend more on the magic spells of the witch doctor than on plants. Although we spent more time with the Waikás than with any other group we obtained no plant medicine information from them. In order to obtain full details of the medicines of any tribe it would be necessary to live with them for a considerable time. Consequently our short visits to the tribes are not sufficient for a proper comparison of their medicines. Nevertheless, for the record of groups fast becoming acculturated, a list is given below of the medicines which we observed in use or were shown by members of the four tribes.

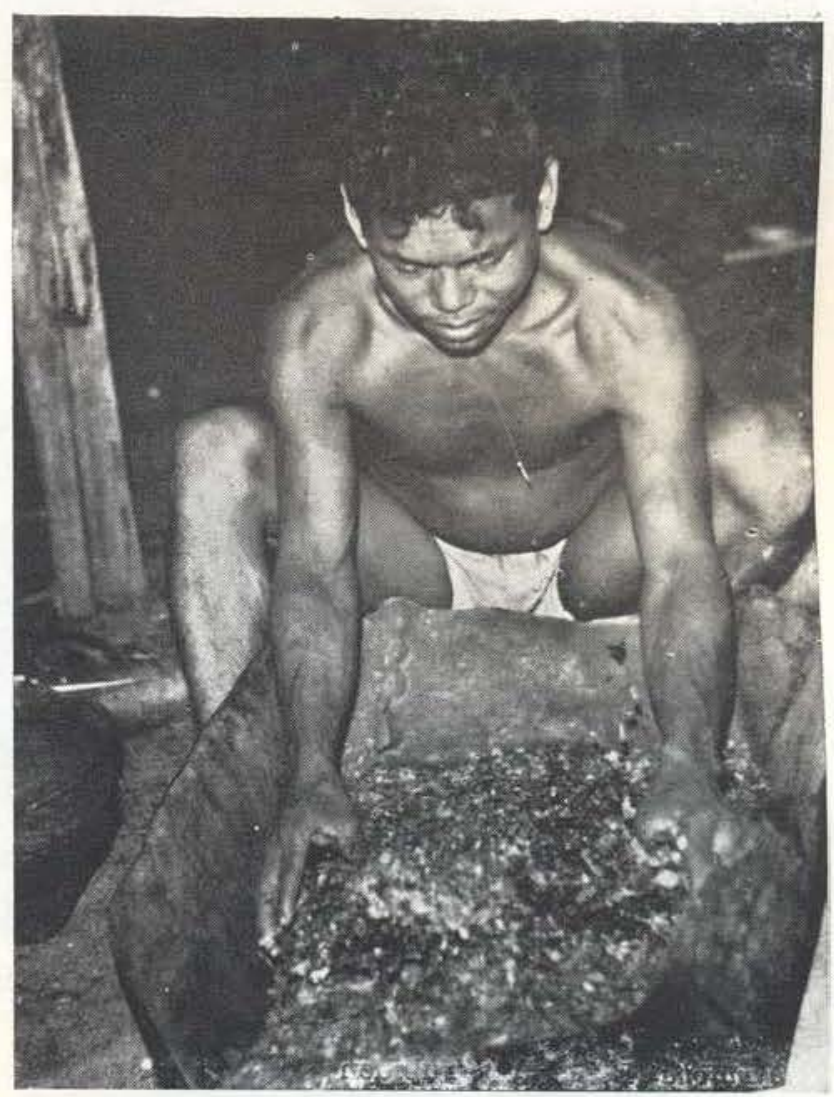

Fig. 13-- A Makú Indian toasting the leaves of Erythroxy. lum coca L. The leaves are toasted, pulverized together with banana leaf ash and the mixed with food. 
Plant

Euphorbiaceae

Piper sp.

Araceae

Solanaceae

Hasseltia sp.

\section{JAMAMADI}

Piper sp.

Piper sp.

Siparuna ef.

guianensis Aubl.

MAKŨ

Urena caracasana

(Jacq.) Griseb.

Bignoniaceae

Sciadotenia ef.

pachnococca

Krukoff \& Barneby

Potalia amara

Aubl.

Chiuk

Tubiden

Tugbiden

Awuibiden

Awuibiden

Myrsinaceae

Endicheria sp.

Rubiaceae

Virola calophylla Warb.

Osteophloem platyspermum
(A.DC.)

Alternanthera

ficoidea (L.)

R. $\mathrm{Br}$.

Euphorbiaceae

Parkia

oppositifolia

Spruce

Euphorbia

thymifolia L.

Bignoniaceae

Piradabi

Tubiden
Indian Name

Inupupu

Patsi

Mapidzu

Unuvana

Mádo

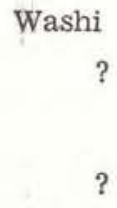

Washi

?

?

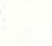

Part Used

latex of inner bark

roots

corm

leaves in bath

stem bark
Cure For

toothache

toothache

sting ray bites

fevers

stomach complaints
Prance et al.

Herbarium Voucher 16342

16387

16400

16402

16486 leaves brewed

toothache

sore throat

13941

leaves brewed into tea

rheumatic

pain scorpion bites

eye drops

for infections

bark

root bark

root bark

toothache

snake bites

mixed with 15560

snake bites mixed with 15559

fever

tongue sores

malaria

Tugnebanpe

bark tea

coughs \& colds

Ocotehugbiden

leaves

root bark

snake bites

trunk bark

dysentery

latex

squashed leaves eye infections

burns
15565

15593

15553

15557

15558

15559

15560

5564

15595

15596

Table 4. Medicinal plants collected 
The table shows that the Makús apparently make the greatest use of plants for medicines The plants listed are used for a wide range of ailments, some of them are probably truly effective, others such as the snake bite remedies probably have no real medicinal value.

\section{CONTRACEPTIVES}

Recently several contraceptives have been reported from various Indian tribes, and the use of contraception by Amazonian tribes is probably more widespread than has been realized in the past. Of the four tribes studied here only the Denís have a contraceptive prepared from the menispermaceous vine Curarea tecunarum Krukoff \& Barneby (Prance et al. 16453). A missionary couple, Paul and Dorothy Moran, who work among the Denis have observed the regular spacing of chiidren in a family, and that the tribe had a definite cycle for conception by which only one woman in the group is pregnant at any given time. The Morans started to enquire within the tribe about their apparent birth control and deduced that it was linked to the drinking of an extract made from the stem of a common menispermaceous liana.

The Denis collect the main stem of the liana and pound it with a hard wood or stone to open it up. (Fig. 14, 15.). The beaten vine is placed in a pan of water to extract the sap. This is filtered through a cloth and is then drunk. The liquid is taken usually a few weeks after a birth. It is drunk in large quantities by both the males and the females. They drink about a gallon of the preparation until it induces vomiting. it is then vomited and followed by a smaller dose which is retained. According

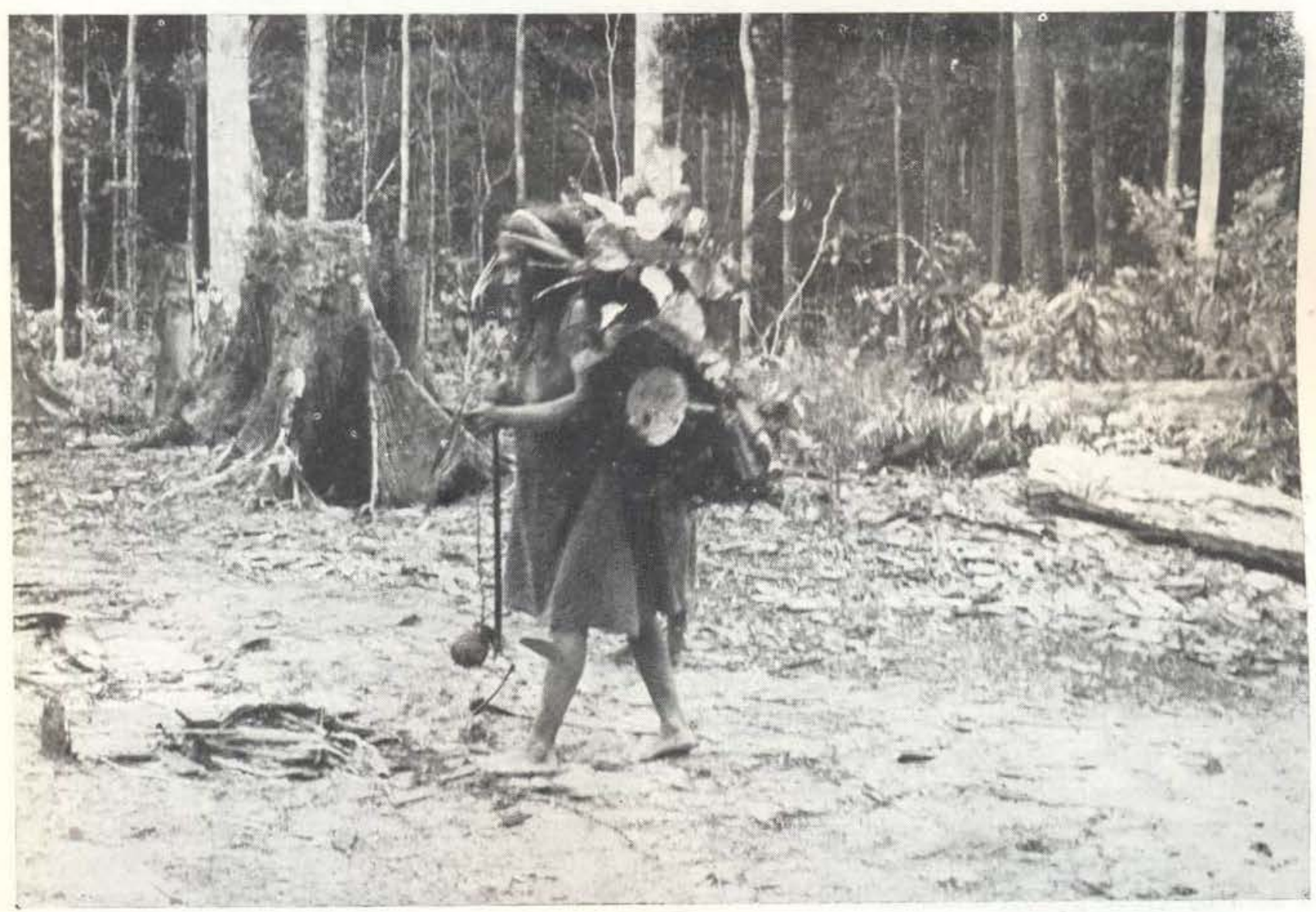

Fig, 14 - A Dení woman bringing in a load of their contraceptive vine Curcrea tecunarum Krukoff and Barneby. She also made many botanical collections for us such as the annonaceous fruit in har hands in the photograph. 


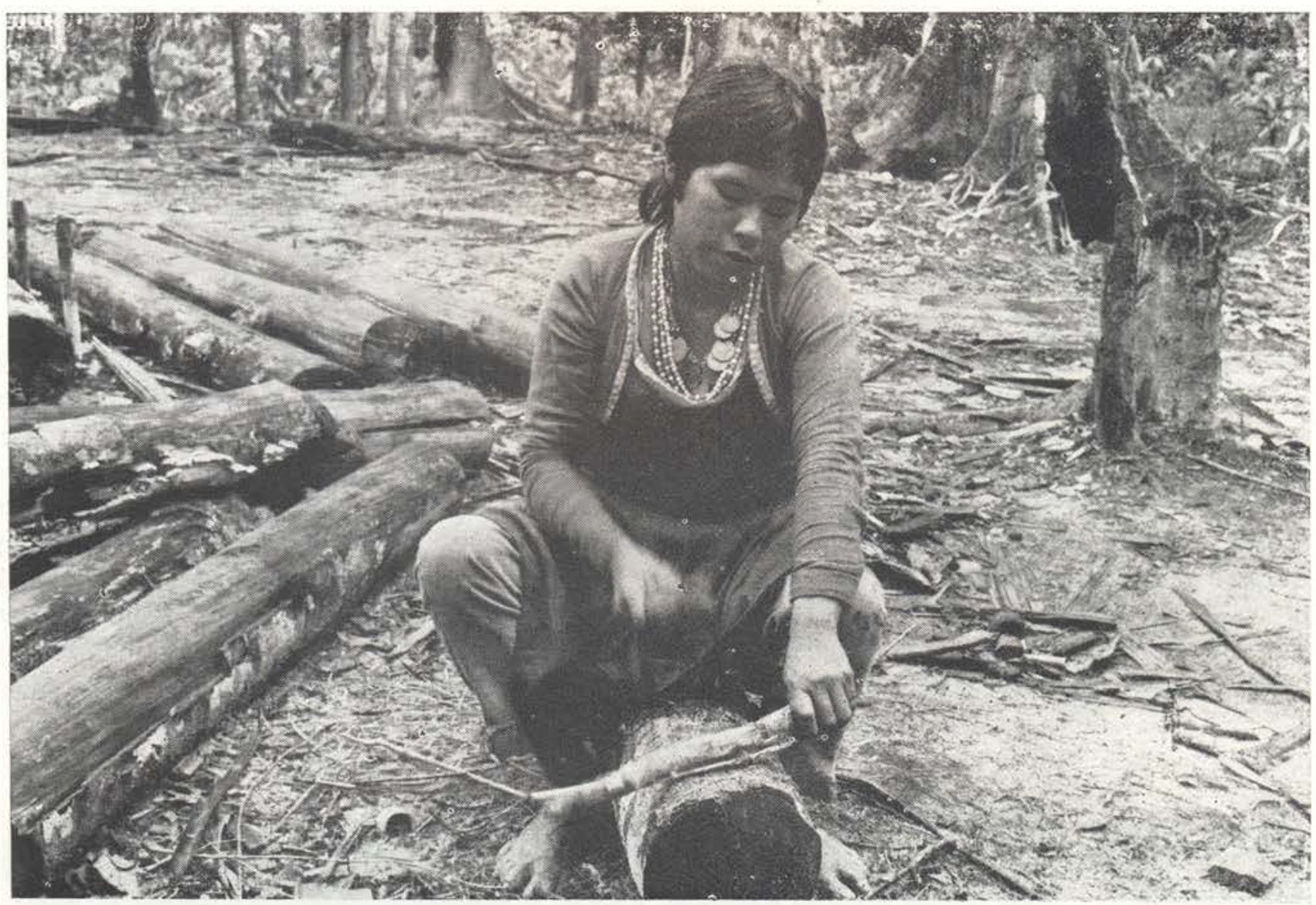

Fig. 15 - a Dení woman pounds the vine Curarea tecinarum Krukoff \& Barneby. The beaten stem is mixed with water and the extract is drunk as a contra-ceptive.

to the Indians a single dose of Bekú is effective for a long time, up to two years. From observations in the tribe it seems possible that " $?$. the active ingredient affects the males rather than the females as the only two women to be pregnant at the same time were the wives of the same man.

It is interesting that this plant, which is drunk in large quantities by the Dení Indians is from the genus Curarea, and from a species which is well known as an ingredient of arrow poisons, see Barneby \& Krukoif (1971), and Krukoff \& Barneby (1970). In the latter work it is cited as the arrow poison of the Kofán Indians in Colombia (page 41, under the old name Chondrodendron iquitanum? also as the arrow poisen of the Tecuna Indians (page 38, under Chondrodendron limaciifolium) Krukoff \& Barneby (1970 p. 38), under C. limaciifolium also give chemical details of three alkaloids found in this species by Barltrop \& Jeffreys
(1954). The latter authors state "the extracts were very toxic but did not produce paralysis".

We have made large collections of the stem of this vine, and await the results of chemical analyses. However, the preliminary laboratory testes show that the crude extract acts as a contraceptive in rats.

SOME MiSCELLANEOUS USES OF PLANTS BY THE FOUR TRIBES

\section{EDIBLE FRUITS}

All tribes of Indians eat a large number or different fruit from the forest. The fruit play an important supplemental part of their diet. To collect a comprehensive list of fruits used by a tribe one would have to spend a full year with them to cover the fruiting season of all the trees. The few wild edible fruits which we observed the Indians eating are listed in Table 5. 
DENÍ

Scientific name

Iryanthera paraensis Hub.

Passiflora sp.

Couepia longipendula Pilg.

WAIKÁ

Apocynaceae

Sapotaceae

Clarisa ilicifolia

(Spreng) Lanjouw \& Rossberg

Spondias mombin $\mathrm{L}$.

Helicostylis tomentosa

(P. \& E.) Rusby

Cucurbitaceae

$\begin{array}{llc}\text { Indian name } & \text { Part used } & \text { Herbarium } \\ \text { Virikitsi } & \text { aril boiled and eaten } & 16451 \\ \text { Tsanaru } & \text { pulp } & 16499 \\ \text { Tsubicutsu } & \text { kernel } & 16521 \\ & & \\ \text { 'Omnamshifi' } & \begin{array}{l}\text { latex drunk, } \\ \text { fruit eaten }\end{array} & 13592 \\ \text { pulp } & 10566 \\ \text { 'Abiufi' } & \text { boiled fruit eaten } & 10622 \\ \text { 'Halina' } & \text { pulp } & 10979 \\ \text { 'Caja', } & & \\ \text { 'Canaxaron' } & \text { pulp } & 11240 \\ \text { 'Xubaco' } & \text { pulp } & 11235 \\ \text { 'Tomeottotorimo' } & \end{array}$

Table 5. Edible fruits collected in tribal areas.
2. THE WAIKÁ EDIBLE FUNGI

The Waikás on the Surucucus-Rio Uraricoeira trail are the only tribe in which I have observed fungi to be an important part of their diet. We collected tour different species of fungus used by the Indians :
'Shikimamok'

'Adamasik'

'Mafcomkuk'

Hodohodokuk
Polyporus dermoporus Pers $=$ Favolus brasiliensis (Fr.) Fr.

Polyporus sp. cf. Favolus tesselatus Mort. or Fexagona subcapercta Murr.

Polyporus stipitarius Berk, \& Curt.

Neoclitocybe bissiseda (Bres.) Sing.
10526, 13602

13615

10515

10516

Table 6. Fungi eaten by the Waikás

To the non-mycologist all of the above fungi look rather similar white masses growing on dead logs, (Fig. 16)., yet the indians readily distinguish them and consistently give the same name to the same species. Their method of preparation also varies. The Agaric, Hodohodokuk, is cooked and the allowed to cool before it is eaten.. The Indians were most insistent that it must be cooked and cooled and would not touch it prepared otherwise. The other three fungi (all Polyporaceae) are eaten raw. The Yanomams or Waikás are not mentioned by Fidalgo (1965) in his review of the mycolo- gical culture of Brazilian Indians. Fidalgo does not list any of the species reported above. The Waikás have a more highly developed knowledge of fungi than any other tribe of indians which I have visited.

\section{BODY PAINTS}

Most tribes like to paint their bodies. Some use extremely elaborate putterns. which signify various aspects of their life, others just smear color onto their bodies. The Waikás use red and black body paints. Their main sources are :
Red :

Maroon :

Black :

Black :

Red :
Bixa orellana $\mathrm{L}$.

Pourouma sp. (Fig. 17)

Charcoal attached to the hody by mixing it with rubber latex

Simaroubaceae (Prance 11091)

Genipa spruceana Steyermark

(Prance 11205)
The aril of the fruit

The pulp of the fruit

Young leaves

Genipa spruceana Steyermark 
The other three tribes are now too near to western civilization, and wear western clothes. Consequently little use is made of body paint.

\section{DENÍ PLAYTHINGS}

Of the four tribes visited, the only one which seemed to have toys and other objects for relaxation was the Denís. Two of these playthings are made from plants.

The Deni spinning top is made from the fruit of Anthodiscus amazonicus Gleason (Prance et al. 16435). They call the tree Tetiaru. The mature fruit is hollowed out and a wooden spindle is inserted through the center. Also two holes are drilled in the side of the fruit so that when it is spun it whistles. The top is spun by winding a string around the spindle and then releasing the top by pulling the string through c. hole in a flat piece of wood held against the spindle. This rotates the top rapidly and spins it fast enough to make it whistle. This is a very popular toy amongst the Denís.

The Denis were also the only tribe to have any sort of a musical instrument that produces different notes of a tonal scale. They have a small four note flute made from the dried fruit of a Sapotaceous tree (Prance 16497) which they call Tukuru The soft inside of the fruit rots out leaving a hard oval endocarp. The Indians drill five holes in the fruit to produce their flute. These flutes are also a great source of recreation to the Denís.

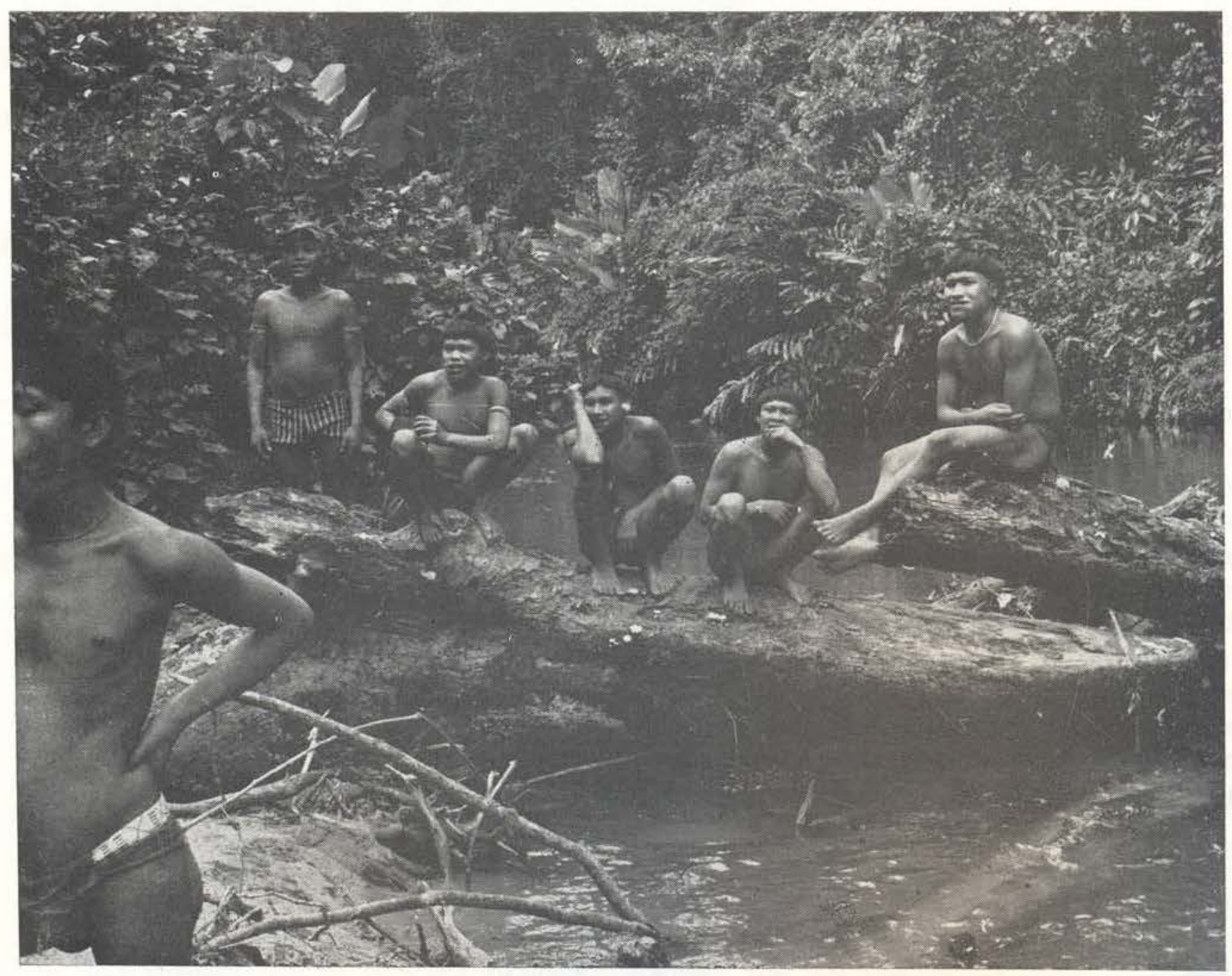

Fig. 16 - A group of Waiká Indians on the Surucus-Waiká trail. The white patches on the log are a species of Poly. porus which forms part of their diet, 


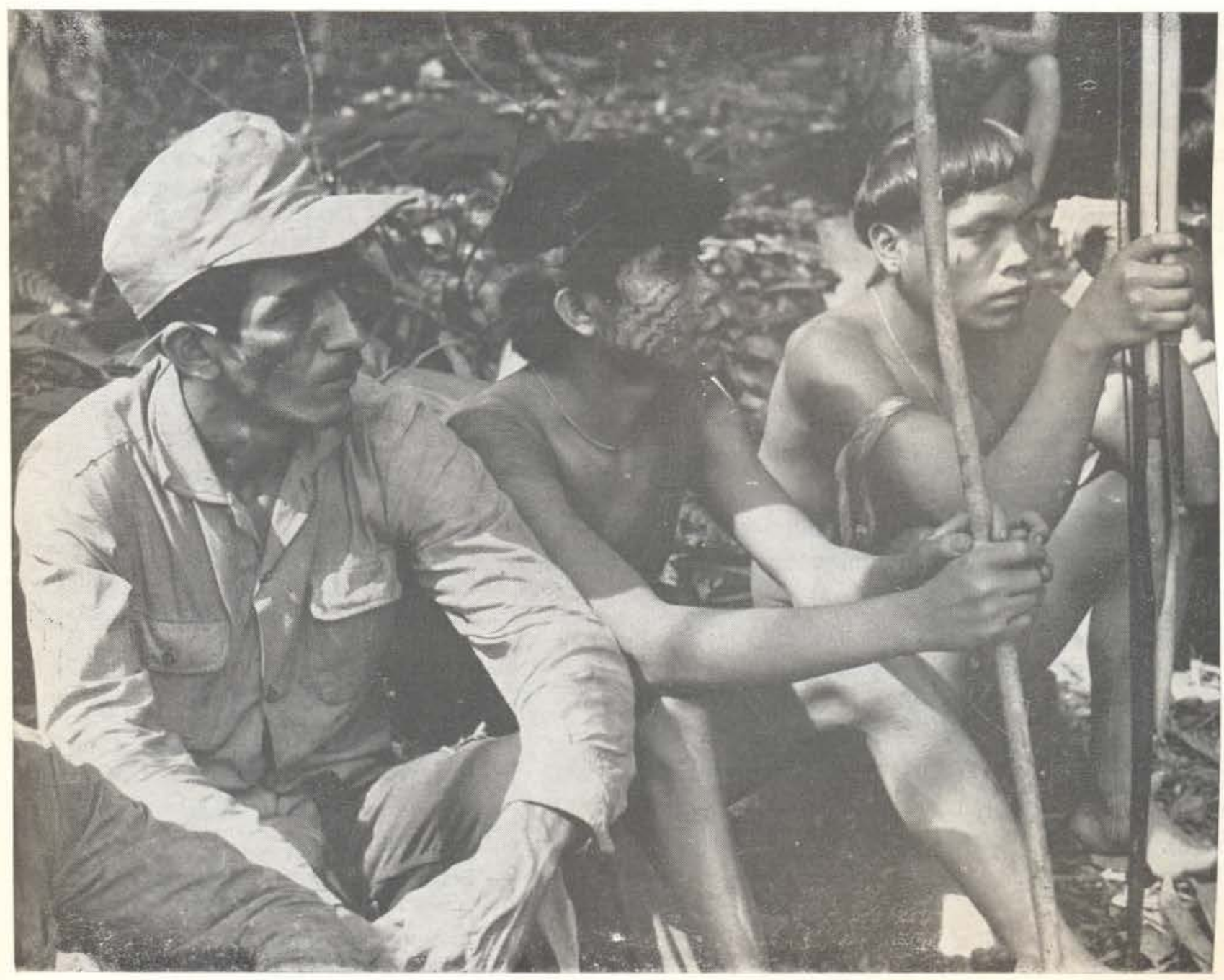

Fig. 17 - The Waikás use body paints frequently. The Indian in the center is painted purple with the juices of the fruit of a species of Pourouma. Osmarino, was also painted by the Indians as a sign of friendship.

\section{POTTERY HARDENER}

The Jamamadis and the Denis make ceramics whereas the Waikás and the Makús which we visited do not. Both tribes which make ceramics use the bark ash of various species of Chrysobalanaceae to harden their clay. Since their pots and jars are made with a spiral coil of clay rather than on a wheel, the clay needs a hardener to maintain its shape before firing. The Indians collect bark from the Caripé trees, burn it and sif $\ell$ it through a fine basketwork sieve. This fine powder, which is rich in silica grains, is added to their clay mixture. The use of Caripé is widespread throughout Amazonia, and it is used by many
Brazilians as well. The following collections of Caripé were made:

$\begin{array}{ccc} & & \text { Dení name } \\ 16521 & \text { Conepia longipendula Pilg. } & \text { Tsubicutsu } \\ 16524 & \text { Licania octandra (Hoffmgg. } & \\ \text { ex R. \& S, Kuntze } & \\ \text { subsp. pallida (Hook, f) } & \\ \text { Prance } & \text { Cubitsa }\end{array}$

\section{ACKNOWLEDGMENTS}

The field work which enalled this study was supported by The National Science Fundation, grant GB-18655, which is gratefully acknowledged. The assistance of the Director and staff of the Instituto Nacional de Pesquisas 
da Amazônia, Manaus, Brazil, and the Director and staff of the New York Botanical Garden made this work possible. I am grateful to the numerous people who assisted us to reach and obtain information from each of the tribes discussed, especially to Sr. Moacir Canizo de Brito, Sr. Frederico Orr, and Sr. Sebastiăo Paiva for the Jamamadis, to Mr. \& Mirs. Paul Moran and the Captain and crew of the INPA motor launch Marupiara for the Denís, to Mr. Joseph Boot for the Makús, and to Mr. Fritz Harter, the Unevangelized Fields Mission Roraima Section, and the Missionary Aviation Fellowship and especially their pilot Lin Entz for the Waikás. I should like to thank the various specialists who have rapidly identified the coilections cited here, Dr. M.K. Arroyo (Leguminosae). Mr. R. Barneby (Menispermaceae), Dr. G.M. Barroso (Compositae), Dr. C.C. Berg (Moraceae), Dr. J. Cuatrecasas (Theobroma), Dr. B.A. Krukoff (Menispermaceae, Strychnos), Dr. W. Punt (Euphorbiaceae), Dr. W. Rodrigues (Myristicaceae), Dr. P. Singer (Fungi), Dr. H. Sleumer (Flacourtiaceae), and Dr. D. Wasshausen (Acantha. ceae).

\section{RESUMO}

Foi feita uma comparação etnobotânica entre quatro tribus: Dení, Jamamadi, Makú e Waiká. Os clados foram colhidos durante uma expedição botânica no território de cada tribu e não devem ser inter. pretados como um estudo etnobotânico completo de cada tribu, sendo apenas uma comparação entre os dados levantados durante uma curta visita. Levando em conta a utilização de plantas, foram distinguidos os seguintes usos: veneno para peixes, venenos para flechas, outros venenos, inalantes, narcóticos e alucinogenicos, coca, medicamentos em geral, anticoncepcionais, fungos e frutos comestiveis e outras formas de utilização de plantas. Pela primeira vez são apresentadas informações sobre o consumo de cogumelos como alimento entre os índios Waiká.

A utilização de diferentes plantas pelas diversas tribus é tabulada em vários quadros. São consideradas observações anteriores e estudos já feitos sokre as plantas consideradas. Foram registradas certas plantas que são utilizadas igualmente pelas quatro tribus, cultivadas como alimento, ou empregadas como venenos com diferentes finalidades, pontas de flechas, e vários usos gerais como material de cons- trução e pintura do corpo. Cada tribu usa um narcótico ligeiramente diferente. Os Jamamadí e os Dení usam um pó inalante à base de tabaco. Já os Waiká possuem vários pós inalantes como efeitos alucinogenicos enquanto entre os Makú o narcótico é a coca, ingerida para aliviar a dor da fome. As pontas das flechas são também diferentes em cada tri. bu. Os Jamadí e os Deni usam um curare à base de Strychnos, os Waiká utilizam um veneno obtido da Virola e os Makú empregam um veneno à base de de Moraceae no qual existem glicosideos de ação sobre o coração. Sob o ponto de vista etnobotânico. Jamandi e Dení são as tribus mais similares e bastantes distintas dos Waiká e dos Makú.

\section{LITERATURE CITED}

Barltrop, J. A. \& JefFreys, J. A. D.

1954 - Curare and related topics. Part 1. A preliminary examination of Chondrodendron limaciifolium. Jour. Chem. Soc., p.: 159-164.

Barneby, R. C. \& Krukoff, B. A.

1971 - Supplementary notes on American Menispermaceae. VIII. A Generic survey of the American Triclisieae and Anomospermeae. Mem. N. Y. Bot. Gard., 22(2): 1-89.

BARREDo-Carneiro, P.

1938 - Les principes actifs du curare. Compt. Rend Acad. Paris, $206+1202-1204$.

1938 - Les principes actifs du arare. Bull. Soc. Chem. Biol., $20: 1125$.

ERNST.

1881 - Memoria botanica sobre el embarbascar ó sea la pesca por media de plantas venenosas. Ann. Acad. Cienc. Habana, 18.: 135-147.

Fidalgo, O.

1965 - Conhecimento micológico dos índios brasileiros Rickia, 2: 1-10.

KILLIP, E. P.

1931 - The use of fish poisons in South America. Ann. Rep. Smithsonian Inst., 1930: 401-408.

KRUKOFF, B. A.

1965 - Supplementary notes on the American species of Strychnos, VII. Mem. N. Y. Bot. Gard., $12(2): 7,42-43$.

Krukoff, B. A. \& Barneby, R. C.

1970 - Supplementary notes on American Menispermaceae. VI. Mem. N. Y. Bot Gard, $20(2): 1-80$.

Krukofr, B. A. \& SMrth, A. C.

1937 - Rotenone-yielding plants of South America. Am. Jour. Bot., 24: 573-587. 
LE COINTE, $P$.

1936 - Les plantes à rotenone em Amazonit. Rev. Bot. Appl., 16: 609-615.

Marino-Bettolo, G. B. et ali

1957 - Nota 8. Gli alcaloidi della Strychnos solimoesana Krukoff. Rend. Instituto Super. Sanita, $20: 342-357$.

Monachino, J.

1949 - A Revision of Ryania (Flacourtiaccae). Lloydia, 12:1-29

PrANCE, G. T.

1970 - Notes on the use of Plant Hailacinogens in Amazonian Brazil. Econ. Bot., 24 : 62-68.
Schultes, R. E.

1954 - A new narcotic snuff the northwest Amazon. Bot. Mus. Leafl, $9: 241-260$.

1957 - A new method of coca preparation in the Colombian Amazon. Bot. Mus, Leafl., 17: 241-246.

1963 - Hallucinogenic plonts of the New World. The Harvard Review, 1: 18-32.

1969a- De Plantis toxicariis e munde novo tropicale commentátiaos. IV. Bot. Mus. Leaf., 22 : 133-164.

$1969 \mathrm{~b}$ - Virola as an orally administered hallucinogen. Bot. Mus. Leafl., 22: 229-240.

SCHULtes, R. E. \& HOLMSTEDT, B.

1968 - The vegetal ingredients of the myristicaceous snuffs of the Northwest Amazon. Rhodora, $70: 113-156$. 